\title{
МОДЕЛЮВАННЯ ЗАКОНОМІРНОСТЕЙ РОЗТАШУВАННЯ МАТЕРІАЛУ ВЗДОВЖ НИЖНЬОЇ ЧАСТИНИ ПІСКОВОГО ТІЛА МЕХАНІЧНОГО СПІРАЛЬНОГО КЛАСИФІКАТОРА
}

\author{
Кондратець B.O. ${ }^{1}$, Мацуй А.М. ${ }^{2}$ \\ ${ }^{1,2}$ Кіровоградський національний технічний університет, Кіровоград \\ E-mail: ${ }^{2}$ Matsuyan@mail.ru \\ ${ }^{1}$ ORCID: 0000-0002-1411-168X \\ ${ }^{2}$ ORCID:
}

Copyright (C) 2014 by author and the journal "Automation technological and business - processes". This work is licensed under the Creative Commons Attribution International License (CC BY). http://creativecommons.org/licenses/by/4.0/

(c) (P) Brit $\begin{aligned} & \text { ONAFT } \\ & \text { Open Access }\end{aligned}$

\begin{abstract}
Аннотация
Підвищення якості автоматичного керування першою стадісю подрібнення вихідної руди на рудозбагачувальних фабриках стримується в наслідок неврахування закономірностей розташування матеріалу вздовж піскового тіла (між двома витками двозахідної спіралі) механічного спірального класифікатора, які несуть достатньо важливу інформацію про хід попереднього і наступного технологічних процесів. Визначення і врахування даної закономірності може суттєво поліпшити якість керування першою стадією подрібнення вихідної руди, знизити енергетичні та матеріальні витрати, що, як наслідок, приведе до підвищення конкурентоспроможності кінцевої продукції - магнетитового концентрату на світовому ринку. Тому розв'язання частини цієї задачі, якій присвячена дана стаття, складає ії актуальність. Метою статті є розроблення підходу математичного моделювання і отримання конкретної закономірності розташування матеріалу вздовж нижньої частини піскового тіла механічного спірального класифікатора. Піскове тіло спірального класифікатора складається з верхньої і нижньої частин. Верхня частина має більш просту форму форму зрізаної піраміді, а нижня - більш складну - форму частини нахиленого циліндра. Нижня частина, якій присвячена стаття, є більш складною і має самостійне значення, оскільки при низьких, середніх і дещо вищих середніх значень циркулюючого навантаження в циклі подрібнення вихідної руди технологічний процес відбувається в області саме цієї частини піскового тіла. Поділивши нижню частину піскового тіла на дев'ять горизонтальних шарів однакової товщини і подаючи кожний шар матеріалу у вигляді трикутника, враховуючи в них крайові ефекти неповного заповнення вздовж вертикалі та знаходячи проекції усіх шарів на верхню горизонтальну площину, проведено графоаналітичне моделювання закономірностей розташування матеріалу вздовж нижньої частини піскового тіла механічного спірального класифікатора. Встановлено, що в механічному спіральному класифікаторі 1КСН-30 нижня частина піскового тіла складає послідовний ряд вертикальних стовпчиків, об'єм матеріалу в яких підпорядкований експоненціальній залежності з максимумом кількості в центральній його частині, який визначається продуктивністю пісків.
\end{abstract}

Ключевые слова

Спіральний класифікатор, піскове тіло, нижня частина, моделювання закономірності.

Abstract

Improving the quality of automatic control of the first stage of grinding feed ore to ore-dressing plants is constrained due to disregard of regularities the location of the material along the sand body (between turns two filar spiral) mechanical spiral classifier, which are quite important information on the pre- and post-production processes. Identification and registration of the patterns can significantly improve the quality of management of the first stage of grinding the original ore, reduce energy and material costs, as a consequence, lead to an increase in the competitiveness of the final product - magnetite concentrate in the global market. Therefore, the solution of this problem, which is the 
subject of this article is its relevance. The aim of the article is to develop a mathematical modeling approach and to obtain the specific location of the laws of the material along the bottom of the sand body mechanical spiral classifier. Sand spiral classifier body consists of top and bottom. The upper portion has a simple shape - the shape of a truncated pyramid, and bottom - more complex - form part of the inclined cylinder. The lower part, which is dedicated to the article, is more complex and has independent significance, because at low, medium and higher average value of the circulating load in the original ore grinding circuit manufacturing process takes place in this part of sand bodies. Dividing the lower part of the sand bodies by nine horizontal layers of equal thickness, and giving each layer of material in the form of a triangle, given them the edge effects incomplete filling along the vertical and finding the projection of all the layers in the upper horizontal plane carried graph-analytical modeling of regularities arrangement of the material along the bottom of the sand body mechanical spiral classifier. It was found that the mechanical spiral classifier 1KSN-30 lower part of the sand body is the serial number of the vertical bars, the volume of material that is subject to an exponential dependence with a maximum amount in the central part of which is determined by the capacity of sand.

Key words

Spiral classifier, sand body, the lower part, modeling patterns.

\section{Вступ}

Основною сировиною чорної металургії України нині є магнетитовий концентрат, який отримують збагаченням бідних залізних руд. Достатньо великі перевитрати електричної енергії і матеріалів у вигляді сталевих або чавунних куль і футеровки у перших стадіях подрібнення вихідної руди на збагачувальних фабриках підвищують його собівартість і тим самим знижують конкурентоспроможність на світовому ринку. Тому перед збагачувальною галуззю стоїть задача зменшення енергетичних і матеріальних витрат при подрібненні руди в перших стадіях, де вони самі великі і здебільшого здійснюються у кульових млинах і механічних спіральних класифікаторах. Одним 3 найбільш важливих напрямів розв'язання цієї задачі є удосконалення автоматичного керування першою стадією подрібненнякласифікації, однак воно стримується, зокрема, в наслідок неврахування інформації стосовно закономірностей розташування матеріалу вздовж піскового тіла механічних спіральних класифікаторів, а більш конкретно - його нижньої частини, яка має визначальне самостійне значення. Оскільки розв'язання даної проблеми відкриває перспективу значного поліпшення показників роботи першої стадії подрібнення - класифікації, тему статті, присвяченої розв'язанню окремої задачі загальної проблеми слід рахувати актуальною. Вона спрямована на реалізацію Галузевої програми енергоефективності та енергозбереження на період до 2017 р., затвердженої наказом Міністра промислової політики України №152 від 25.02.2009 року в частині гірничо-металургійного комплексу та плану наукових досліджень Кіровоградського національного технічного університету.

Огляд сучасного стану розв'язання проблеми

Автоматизацією першої стадії подрібнення вчені і практики займаються давно як закордоном, так і в Україні. Однак є ряд нерозв'язаних задач і собівартість вітчизняного магнетитового концентрату поступається порівняно 3 зарубіжними аналогами. Тому в останні роки ведучі вчені України звертають на це увагу, повертаючись до даної тематики досліджень. Так, наприклад, в роботі [1] розглядається робастне автоматизоване керування замкнутим циклом подрібнення на основі $H_{\infty}$-норми, в роботі [2] показано, що автоматизація першої стадії подрібнення, класифікації і магнітної сепарації є реальним шляхом підвищення ефективності збагачення залізних руд та ін. В останні роки розробляються ефективні засоби контролю технологічних параметрів у збагачувальній галузі [3]. В той же час розробка первинних засобів контролю технологічних параметрів відстає. Запропоновано лише спосіб визначення об'єму піскового тіла [4]. Закономірність розташування матеріалу вздовж піскового тіла, зокрема його нижньої частини, яка має самостійне значення, ніхто не досліджував.

Мета досліджень

Метою досліджень було розроблення підходу математичного моделювання і отримання закономірностей розташування матеріалу вздовж нижньої частини піскового тіла механічного спірального класифікатора.

Виклад основного матеріалу

Закономірності розташування матеріалу вздовж нижньої частини піскового тіла у механічному спіральному класифікаторі розглянемо на конкретному типі технологічного агрегату 1-КСН-30, який встановлюють під кутом $18^{\circ} 30^{\prime}$ до горизонту. Його спіраль діаметром 3 м, виконана двозахідною 3 кроком 1,8 м, звичайно обертається зі швидкістю 3 об/хв. (0,05 об/с) і обладнана робочими елементами висотою 0,33 м [5].

Нижня частина піскового тіла розташована між двома витками спіралі, встановленої разом 3 корпусом класифікатора під кутом $\alpha=18^{\circ} 30^{\prime}$ до горизонту, займає простір вздовж вертикалі до рівня, коли матеріал, що розташовується горизонтально у верхній площині, підходить до нижньої основи попереднього витка (рис.1). Знизу піскове тіло механічного спірального класифікатора обмежується постіллю циліндричної форми, яка створюється 3 пісків при обертанні спіралі. Кінцеве піскове тіло (знаходиться між двома витками біля піскового порога механічного спірального класифікатора) під дією рухомої спіралі витісняється з циліндричної постелі, тобто, сходить у пісковий жолоб класифікатора. Нижня частина піскового тіла механічного спірального класифікатора ліворуч за напрямом руху 
має найменшу товщину, яка збільшується і приймає максимальне значення біля основи заднього штовхаючого витка. Тому сходження матеріалу буде нерівномірним. Максимальне значення висоти матеріалу є константою для класифікатора і дорівнює

$$
h_{c}=\frac{B}{2} \sin \alpha,
$$

де $B$ - крок спіралі; $\alpha$ - кут нахилу корпуса класифікатора до горизонталі.

Для прийнятого класифікатора цей параметр складає $h_{c}=0,28557$ м.

Оскільки нижня частина піскового тіла складна за формою, подамо іï у вигляді кількох горизонтально розташованих шарів матеріалу однакової товщини $\Delta h$. Враховуючи те, що величина $h_{c}$ жорстко зв’язана 3 конструкцією класифікатора, іiі треба брати за основу при виборі інтервалу $\Delta h$. Чим меншим буде інтервал $\Delta h$, тим точнішим буде результат моделювання, однак при цьому непомірно зростають обсяги обчислень. Тому тут необхідно перш за все виходячи з забезпечення допустимої точності оцінювання сходження піскового тіла класифікатора. На відрізку $h_{c}$ повинна розміститись певна кількість однакових шарів матеріалу $\Delta h$. Аналіз показав, що достатня точність моделювання сходження пісків класифікатора буде отримана при $\Delta h=31,8$ мм. При цьому на відрізку $h_{c}$ точно вміщується 9 шарів матеріалу висотою 0,0318 м.

Кут нахилу витків спіралі до осі її обертання дорівнює

$$
\gamma=\operatorname{arctg} 4 R_{c} / B
$$

де $R_{c}$ - радіус спіралі.

Для даного механічного спірального класифікатора $\gamma=\operatorname{arctg} 3,3333=73^{\circ} 20^{\prime}$.

Моделювання нижньої частини піскового тіла механічного спірального класифікатора доцільно розпочинати 3 верхньої геометричної фігури горизонтального розрізу на стику двох частин - нижньої і верхньої. Вона має форму, обмежену параболою і нахиленою під кутом $\gamma$ прямою, що характеризує лінію змочування на робочих елементах подаючого витка спіралі. У нижніх шарах форма фігур у горизонтальних перетинах піскового циліндричного тіла повторюється при зменшених розмірах, що характеризується довжиною відповідних ліній змочування. Площі цих геометричних фігур вздовж осі спіралі $l$ також $є$ змінними, тому їх доцільно оцінювати на елементарних ділянках довжиною $\Delta l$. Аналіз показав, що відрізок $\Delta l$ може дорівнювати 0,05 м. При цьому процес сходження кінцевого піскового тіла у пісковий жолоб механічного спірального класифікатора можливо характеризувати об'ємами пісків, що знаходяться у елементах довжиною $\Delta l$. Об'єм пісків у конкретному шарі матеріалу дорівнює площі геометричних фігур довжиною $\Delta l$, помноженій на висоту шару матеріалу $\Delta h$. Тобто, знаходження об'ємів матеріалу в елементарних складових піскового тіла зводиться до визначення площ відповідних геометричних фігур довжиною $\Delta l$. Елементарні складові піскового тіла вздовж вертикальної осі повинні бути вирівняними, не мати відносних зсувів у горизонтальних площинах. Розріз нижньої частини піскового тіла класифікатора вздовж осі спіралі видно 3 рис.1. 3 рис.1 слідує, що при складній формі нижньої частини піскового тіла і прийнятих розмірах його елементарних складових $\Delta l$ і $\Delta h$ мають місце не повністю заповнені структури, які зафарбовано. Їх об'єми слід віднести до сусідніх елементів або знехтувати ними. Це не вплине суттєво на точність моделювання процесу. Подібний ефект необхідно враховувати і на циліндричних бічних поверхнях окремих шарів нижньої частини піскового тіла.

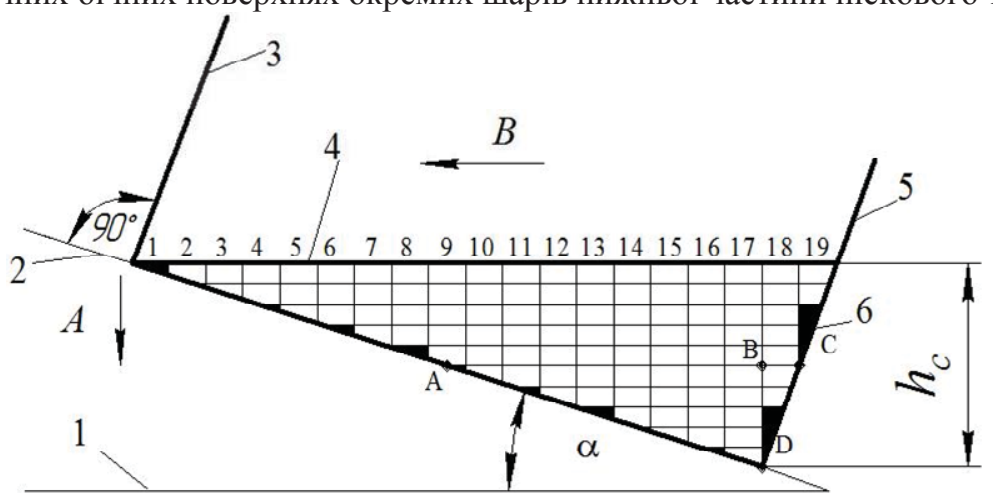

1 - горизонталь; 2 - нахилене дно циліндричної постелі, створене з пісків класифікатора; 3 - передній виток спіралі; 4 -горизонтальна поверхня нижньої частини піскового тіла, яка обмежує його максимальний розмір; 5 - задній

(подаючий) виток спіралі; 6 - неповні елементи піскового тіла; А - напрям і місце сходження пісків; В - напрям подачі пісків; 1-19 - номера вертикальних стовпчиків з матеріалом

Рис.1 - Нижня частина піскового тіла механічного спірального класифікатора, представлена елементарними складовими з розмірами $\Delta h \mathrm{i} \Delta l$

Як слідує з рис.1, у нижній частині піскового тіла спірального класифікатора у самому верхньому шарі матеріалу елементарні складові у стовпчику 1 можуть бути відсутніми, тоді облік розпочнеться лише 3 стовпчика 2 , куди входить один елемент. У другому шарі матеріалу облік розпочнеться лише з елементарної складової, розташованої у стовпчику 3 і т.д. Найбільше матеріалу буде у стовпчику 17. Зі стовпчиків 18 і 19 матеріал практично буде 
розвантажуватись одночасно, оскільки він зсувається 3 круто нахиленої площини. Для визначення «ваги» елементарних складових нижньої частини піскового тіла проведемо більш детальний аналіз.

В прямокутних трикутниках $A B D$ і $D B C$ (рис.1) катет $B D \in$ спільним і його можливо задавати у кількості складових $\Delta h$, де величина змінюється від 1 до 9. 3 трикутника $A B D$ катет $A B=B D / \operatorname{tg} \alpha$, а 3 прямокутного трикутника $D B C$ катет $B C=B D \cdot \operatorname{tg} \alpha$. Горизонтальний відрізок $A C=A B+B C$. Для різних шарів матеріалу визначимо параметри $A B$, $B C$ і $A C$ та кількість елементарних складових $\Delta l$ в них. Дані зведемо в табл. 1.

Табл. 1 - Значення довжини відрізків у горизонтальних шарах нижньої частини піскового тіла механічного спірального класифікатора та кількості елементарних складових $\Delta l$ в них

\begin{tabular}{|c|c|c|c|c|c|c|}
\hline $\begin{array}{c}\text { Найбільша } \\
\text { висота } \\
\text { матеріалу, } \\
\begin{array}{c}\text { подана у } \\
\text { одиницях } \Delta h, \\
\text { м }\end{array}\end{array} \quad \begin{array}{c}\text { Довжина } \\
\text { відрізка } A B, \mathrm{~m}\end{array}$ & $\begin{array}{c}\text { Кількість } \\
\text { елементарних } \\
\text { складових } \Delta l \mathrm{y} \\
\text { відрізку } A B\end{array}$ & $\begin{array}{c}\text { Довжина } \\
\text { відрізка } B C, \mathrm{~m}\end{array}$ & $\begin{array}{c}\text { Кількість } \\
\text { елементарних } \\
\text { складових } \Delta l \mathrm{y} \\
\text { відрізку } B C\end{array}$ & $\begin{array}{c}\text { Довжина } \\
\text { відрізка } A C, \text { м }\end{array}$ & $\begin{array}{c}\text { Кількість } \\
\text { елементарних } \\
\text { складових } \Delta l \text { у } \\
\text { відрізку } A C\end{array}$ \\
\hline $9 \Delta h=0,2853$ & 0,8527 & 17,05 & 0,0955 & 1,91 & 0,9482 & 18,96 \\
\hline $8 \Delta h=0,2536$ & 0,7579 & 15,16 & 0,0848 & 1,70 & 0,8427 & 16,85 \\
\hline $7 \Delta h=0,2219$ & 0,6632 & 13,26 & 0,0742 & 1,48 & 0,7374 & 14,75 \\
\hline $6 \Delta h=0,1902$ & 0,5684 & 11,37 & 0,0636 & 1,27 & 0,6320 & 12,64 \\
\hline $5 \Delta h=0,1585$ & 0,4737 & 9,47 & 0,0530 & 1,06 & 0,5267 & 10,53 \\
\hline $4 \Delta h=0,1268$ & 0,3790 & 7,58 & 0,0424 & 0,85 & 0,4214 & 8,43 \\
\hline $3 \Delta h=0,0951$ & 0,2842 & 5,68 & 0,0318 & 0,64 & 0,3160 & 6,32 \\
\hline $2 \Delta h=0,0634$ & 0,1895 & 3,79 & 0,0212 & 0,42 & 0,2107 & 4,21 \\
\hline $1 \Delta h=0,0317$ & 0,0947 & 1,89 & 0,0106 & 0,21 & 0,1053 & 2,11 \\
\hline
\end{tabular}

3 даних табл.1 слідує, що при зменшенні рівня матеріалу $B D$ (рис.1) у міжвитковому просторі спірального класифікатора загальна кількість елементарних складових $\Delta l$ на відрізку $A C$ зменшується 3 18,96 до 2,11. При переміщенні подаючого витка 5 (рис.1) у напрямі стрілки $B$ матеріал розвантажується через пісковий поріг класифікатора в напрямі стрілки $A$ до піскового жолоба, починаючи з самого верхнього шару. Товщина матеріалу у часі збільшується відповідно висоті стовпчиків на рис.1. Оскільки при зменшенні висоти пісків $B D$ при зменшенні їх продуктивності початки нижніх шарів матеріалу зміщуються праворуч, то відлік початку вертикальних стовпчиків (рис.1) слід розпочинати від вертикалі $B D$ ліворуч і праворуч. Матеріал у стовпчиках (рис.1), розташованих ліворуч вертикалі $B D$ сходять у пісковий жолоб під дією власної ваги, відриваючись від загального масиву, а матеріал, розташований праворуч даної вертикалі, також сходить під дією власної ваги, але ковзаючи вздовж круто нахиленої площини робочих елементів витка 5. При цьому матеріал у стовпчиках, розташованих праворуч вертикалі $B D$, сходить у пісковий жолоб практично одночасно. Тому формування вертикальних стовпчиків матеріалу ліворуч граничної лінії $B D$ слід розглядати саме від цієї вертикалі до кінця конкретного шару пісків. Для визначення об'єму пісків у елементарних складових нижньої частини піскового тіла спірального класифікатора, крім того, необхідно розглядати горизонтальні перерізи піскового тіла, а також визначати об'єми матеріалу в конкретних шарах.

Верхній шар нижньої частини піскового тіла спірального класифікатора у горизонтальній площині показано на рис.2. Він відповідає рівню матеріалу $h_{c}$ і лінії змочування ним заднього витка спіралі, розташованого під кутом $\gamma=73^{\circ} 20^{\prime}$ довжиною 1,84 м. Нижня частина піскового тіла класифікатора своїм верхнім шаром лише торкається переднього витка спіралі. Бокові сторони фігури, що знаходяться у горизонтальній площині, проходять від точки торкання до кінців лінії змочування вздовж циліндричної поверхні. При малій крутизні поверхні їх можливо рахувати прямими. Тоді самий верхній шар матеріалу нижньої частини піскового тіла спірального класифікатора можливо подати у вигляді трикутника або геометричної фігури, створеної параболою, обмеженою лінією змочування подаючого витка спіралі (рис.2). Як показав аналіз, подання верхнього шару нижньої частини піскового тіла спірального класифікатора у вигляді трикутника не забезпечує самої високої точності. Більш задовольняє умовам моделювання подання іiі у вигляді параболи, обмеженої прямою (рис.2).

Отриману на рис.2 геометричну фігуру можливо подати 19-ма складовими, якщо провести через інтервали $\Delta l$ прямі, паралельні лінії змочування. Тоді геометричну фігуру доцільно розглядати як трапецію. Це можливо зробити зважаючи на те, що різниця у довжині відрізків такої геометричної фігури, проведених паралельно лінії змочування і перпендикулярно осі невелика. Невеликими є і зміни площ геометричних фігур. Тому при визначенні об' єму пісків у окремих шарах геометричні фігури будемо рахувати трапеціями з незмінною висотою $\Delta h$, відносячи до невеликого варіювання бокових розмірів трапеції незаповнені до кінця елементарні складові піскового тіла. 3 іншого боку, знайдену геометричну фігуру (рис.2) можливо розбити на 25 елементарних складових довжиною $\Delta l$.

Верхній шар нижньої частини піскового тіла спірального класифікатора у горизонтальній площині будемо подавати у вигляді трапеції (рис.2) 3 короткою верхньою основою $a$, висотою $h_{T}=0,95$ м $\cdot \sin 73^{\circ} 20^{\prime}=0.91$ м і нижньою основою $b=1,84$ м. При цьому площа трапеції дорівнює 


$$
S_{T}=\frac{a+b}{2} \cdot h_{T} .
$$

У рівнянні (3) дві невідомі величини - площа трапеції $S_{T}$ і верхня основа $a$.

Об'єм верхнього шару матеріалу нижньої частини піскового тіла спірального класифікатора дорівнює $V_{B}=S_{T} \Delta h$. Знаючи об’ єм матеріалу у верхньому шарі, визначаємо його меншу основу

$$
a=\frac{2 V_{B}}{\Delta h h_{T}}-b .
$$

Отже, за відомим об'ємом матеріалу у конкретному шарі нижньої частини піскового тіла спірального класифікатора, за відомими $\Delta h, h_{T}$ і $b$ можливо знайти верхню основу $а$ трапеції і побудувати іiі, розбивши на окремі складові лініями, перпендикулярними проекції осі обертання спіралі на горизонтальну площину (рис.2). Це відкриває шлях аналітичного підходу моделювання.

За точними значеннями площ окремих складових визначаємо об'єми матеріалу в них. Менша основа початкової трапеції на ділянці $A$ (рис.2) відома. Більша основа будь-якої трапеції на даній ділянці може визначатись відповідно залежності

$$
h_{A n}=h_{M 1}+n \Delta l\left(\operatorname{tg} \gamma_{1}+\operatorname{tg} \gamma_{2}\right) \text {, }
$$

де $n$ - порядковий номер трапеції, що знаходиться в основі елементарної складової нижньої частини піскового тіла спірального класифікатора; $h_{M 1}$ - відома менша основа трапеції.

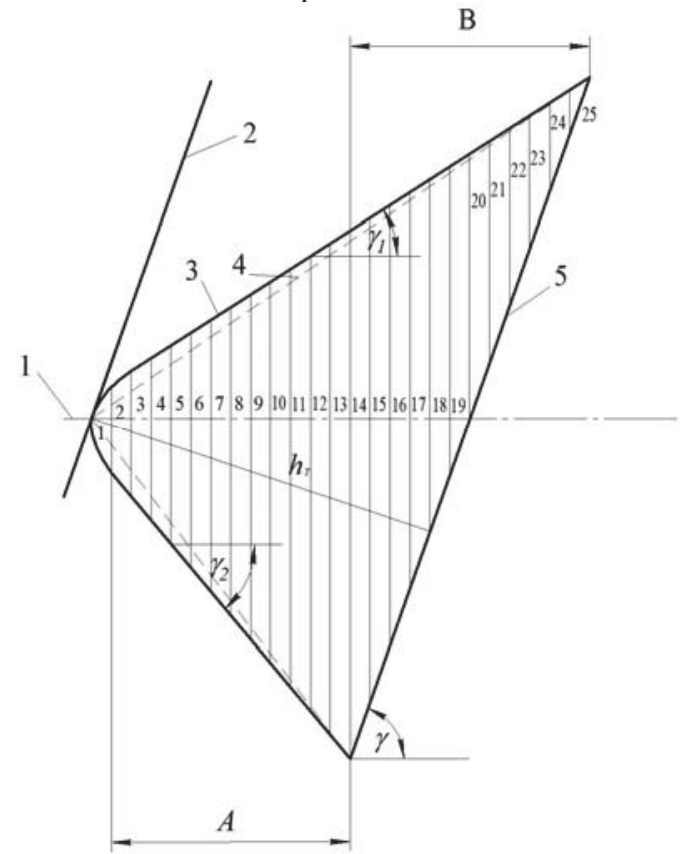

1 - проекція осі обертання на горизонтальну площину; 2 - проекція нижньої частини переднього витка на горизонтальну площину; 3 - верхній шар піскового тіла у формі параболи, обмеженої прямою; 4 - верхній шар піскового тіла у формі трикутника; 5 - змочена лінія на задньому (подаючому) витку спіралі; 1 ...25 - елементарні складові піскового тіла довжиною $\Delta \mathrm{l}$

Рис. 2 - Подання горизонтальної площини верхнього шару нижньої частини піскового тіла спірального класифікатора параболою, обмеженою нахиленою прямою

На ділянці $B$ (рис.2) розрахунки слід виконувати, починаючи з трикутника 25 за відомою висотою $\Delta l$ і взятою 3 креслення основою $h_{M 2}$. Нижня основа будь-якої трапеції на ділянці $B$ дорівнює

$$
h_{B n 1}=h_{M B}+\Delta l\left(n_{1} / \operatorname{ctg} \gamma-\operatorname{tg} \gamma_{1}\right),
$$

де $n_{1}$ - порядковий номер трапеції на ділянці $B$ після трикутника.

За цими даними знаходимо площі елементарних складових піскового тіла, а за відомою висотою $\Delta h-\ddot{1 x}$ об' $є м и$.

Нижня частина піскового тіла класифікатора являє собою відрізок циліндра. Для визначення об'єму відрізка циліндра в [6] запропоновано залежність. Удосконалена залежність [7] дозволяє іiі використовувати для змінних параметрів. Вона має наступний вигляд

$$
V_{B C}=\frac{R_{c}^{3}}{\operatorname{tg} \alpha}\left(\sin \beta-\frac{\sin ^{3} \beta}{3}-\beta_{p} \cos \beta\right),
$$

де $\beta$ - половина центрального кута, що опирається на змінні хорди циліндричного тіла; $\beta_{p}$ - кут $\beta$ в радіанах. 
Кут $\beta$ при рівні матеріалу $h_{c}$ буде найбільшим, найбільшим буде і об'єм відрізка циліндра $V_{B C l}$. Зменшивши $h_{c}$ на висоту одного шару матеріалу $\Delta h$, знайдемо об'єм відрізка циліндра $V_{B C 2}$. Різниця цих об'ємів дорівнює об'єму матеріалу у верхньому шарі нижньої частини піскового тіла спірального класифікатора. Розрахунки показують, що об'єм матеріалу в даному шарі дорівнює 0,024 м³. Порівняємо цей об'єм з об' ємом матеріалу, знайденим відповідно геометричній фігурі верхнього шару нижньої частини піскового тіла, зображеній на рис.2 Розглянемо варіант, що забезпечує мінімальний об’ єм матеріалу в цьому шарі, визначаючи його за площею трикутника, який показано пунктиром на рис.2. Відповідно рис.2 площа верхнього шару нижньої частини піскового тіла спірального класифікатора у формі трикутника дорівнює 82,8 дм² , а його об'єм при $\Delta h=0,317$ дм - 26,25 дм³, що більше на 8,57\%. При менших площах горизонтально розташованих геометричних фігур нижньої частини піскового тіла похибки можуть бути ще більшими. Якщо брати не трикутник, а трапецію в основі шару матеріалу, що відповідає фізичній суті процесу, похибка при моделюванні буде значно зростати, як це видно з рис.2. Оскільки формула (7) не забезпечує достатньої точності визначення об'єму матеріалу в конкретному шарі нижньої частини піскового тіла спірального класифікатора, моделювання закономірностей розташування матеріалу вздовж неї недоцільно виконувати аналітичним шляхом. Значно кращі результати може забезпечити графоаналітичний підхід 3 повним перебором елементарних складових, з врахуванням крайових ефектів. Як показав аналіз з достатньою для практики точністю можливо розглядати трикутні геометричні фігури.

Розглянемо даний підхід відповідно шару матеріалу, розташованому на рівні, що дорівнює $5 \Delta h=0,1585$ м. При цьому змочена пряма на подаючому витку спіралі має довжину 1,4 м. 3 даних табл.1 слідує, що кількість елементарних складових $\Delta l$ у відрізку $A B$ складає 9,47 , а у відрізку $B C-1,06$. Геометрія даного шару матеріалу в горизонтальній площині, отримана як проекція на зовнішню поверхню верхнього шару матеріалу нижньої частини піскового тіла, показана на рис.3.

3 рис.3 видно, що геометрична фігура 2 верхнього шару матеріалу нижньої частини піскового тіла має найбільші розміри. На неї будуть проектуватись геометричні фігури інших шарів матеріалу нижньої частини піскового тіла. На рис.3 показані проекції геометричної фігури 3 п’ятого знизу шару матеріалу і четвертого 5 шару. Лінії на рис.3 визначають контури 3 і 5 геометричних фігур цих шарів матеріалу. Між контурами 3 і 5 товщина шару матеріалу змінна - змінюється практично від нуля до $\Delta h=0,0317$ м. Аналіз показав, що середня лінія між цими контурами в основному відповідає рівню матеріалу $\Delta h$. Тому на рис.3 виконана побудова середньої лінії 4 , яка враховує зміни товщини шару на нахилених і циліндричних поверхнях. Таку фігуру 4 назвемо нормалізованою. Вона буде в середньому характеризувати даний шар матеріалу. Як показав аналіз, початкова частина нормалізованого шару відрізняється меншою товщиною, якою можливо знехтувати. Тому в межах одного елемента $\Delta l$ або дещо більшої ширини необхідно виключити початкову частину нормалізованого шару матеріалу 3 обліку. Ця частина нормалізованого шару на рис.3 заштрихована. Така проекція будь-якого нормалізованого шару матеріалу дозволяє графоаналітично визначати об'єми елементарних складових нижньої частини піскового тіла спірального класифікатора. Для визначення об’ємів елементарних складових необхідно виміряти середню лінію трапецій шириною $\Delta l$, помножити iї на ширину $\Delta l$ і висоту $\Delta h$.

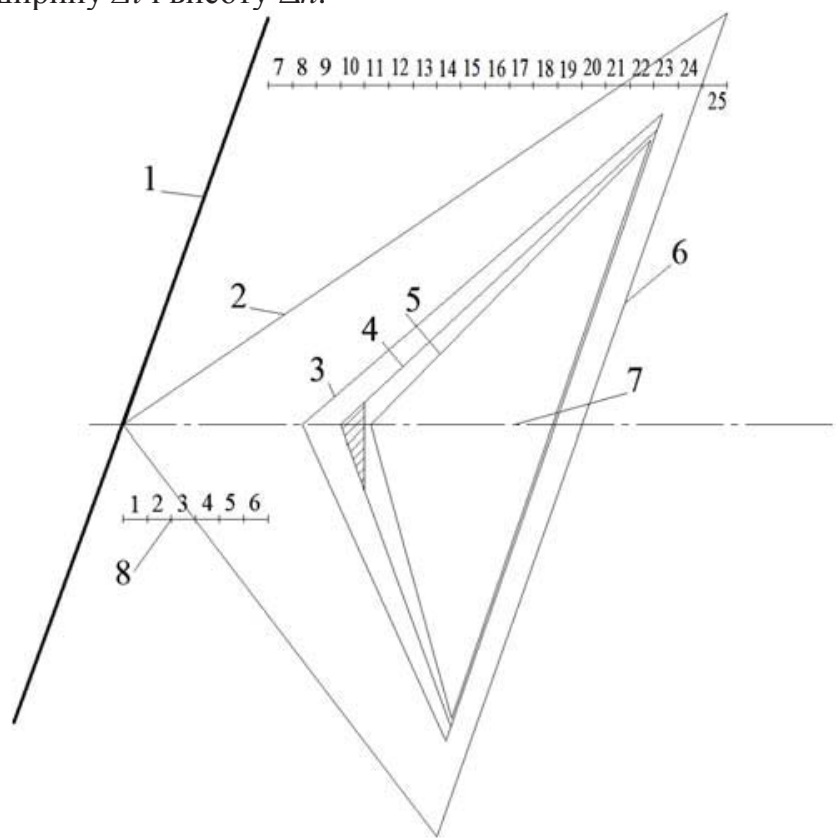

1 - проекція переднього витка спіралі на площину, у якій знаходиться верхня поверхня верхнього шару нижньої частини піскового тіла спірального класифікатора; 2 - геометрична фігура верхнього шару; 3, 4, 5 - відповідно проекції геометричних фігур п'ятого, нормалізованого і четвертого шару матеріалу на ту ж площину; 6 - змочена 
пісковим тілом лінія на задньому (подаючому) витку спіралі у тій же площині; побудови проекцій; 8 - номера стовпчиків з матеріалом

Рис.3 - Отримання нормалізованої геометричної фігури п’ятого шару матеріалу для визначення параметрів елементарних складових нижньої частини піскового тіла

Нижня частина піскового тіла спірального класифікатора буде подана усіма шарами матеріалу. Для визначення елементарних складових піскового тіла необхідно отримати відповідно рис.3 проекції нормалізованих шарів матеріалу. Побудова проекцій шарів матеріалу базується на визначенні його висоти у відрізках $\Delta h$ і безпосередньо в одиницях довжини, довжини змоченої лінії на подаючому витку, відстаней від вертикалі $B D$ на рис.1 до початку розташування пісків та змоченої лінії на подаючому витку для конкретного шару. Такі дані приведені в табл.2, а проекції нормалізованих геометричних фігур, що відповідають шарам нижньої частини піскового тіла, на горизонтальну площину, в якій знаходиться верхня поверхня найвищого шару, - на рис.4. 3 рис.4 видно, що проекції будь-якої геометричної фігури мають елементарні складові, які розташовуються симетрично відносно вертикальної площини, що перпендикулярна осі обертання спіралі і проходить через центральну точку 12. У вертикальному напрямі елементарні складові кожного шару матеріалу створюють стовпчики шириною $\Delta l$, які вміщують різну кількість елементів, що визначається як рівнем пісків між витками спіралі, так і положенням конкретного стовпчика вздовж піскового тіла спірального класифікатора.

Табл. 2 - Дані для побудови нормалізованих геометричних фігур при моделюванні закономірностей розташування матеріалу вздовж нижньої частини піскового тіла механічного спірального класифікатора

\begin{tabular}{|c|c|c|c|c|}
\hline $\begin{array}{c}\text { Висота } \\
\text { катеріалу в } \\
\text { кількості } \\
\text { елементарних } \\
\text { складових } \Delta h\end{array}$ & $\begin{array}{c}\text { Висота } \\
\text { матеріалу } h, \mathrm{~m}\end{array}$ & $\begin{array}{c}\text { Довжина } \\
\text { змоченої } \\
\text { прямої на } \\
\text { подаючому } \\
\text { витку, м }\end{array}$ & $\begin{array}{c}\text { Відстань від вертикалі } \\
\text { визачення висоти матеріалу }\end{array}$ & $\begin{array}{c}\text { Відстань від вертикалі } \\
\text { визначення висоти матеріалу } h \\
\text { пісків у шозташування м } \\
\text { зо відповідає даному на шиткару, м }\end{array}$ \\
\hline $1 \Delta h$ & 0,0317 & 0,64 & 0,095 & 0,011 \\
\hline $2 \Delta h$ & 0,0634 & 0,90 & 0,190 & 0,021 \\
\hline $3 \Delta h$ & 0,0951 & 1,10 & 0,284 & 0,032 \\
\hline $4 \Delta h$ & 0,1268 & 1,26 & 0,379 & 0,042 \\
\hline $5 \Delta h$ & 0,1585 & 1,4 & 0,474 & 0,053 \\
\hline $6 \Delta h$ & 0,1902 & 1,52 & 0,568 & 0,074 \\
\hline $7 \Delta h$ & 0,2219 & 1,64 & 0,663 & 0,085 \\
\hline $8 \Delta h$ & 0,2536 & 1,74 & 0,758 & 0,096 \\
\hline
\end{tabular}

Побудови на рис.4 дозволяють досліджувати розташування матеріалу вздовж нижньої частини піскового тіла механічного спірального класифікатора при будь-якій висоті пісків, кратній $\Delta h$ в межах нижнього піскового тіла. Розглянемо випадок закономірності розташування матеріалу вздовж нижньої частини піскового тіла при його найбільшій висоті $h_{c}$. 3 рис.4 видно, що матеріал у першому і другому стовпчиках відсутній. У третьому і четвертому вертикальному стовпчику фігурує лише самий верхній шар матеріалу. Тому об'єми елементарних складових у них будуть дорівнювати добутку середніх ліній трапецій, їх довжини $\Delta l$ і висоти шару $\Delta h$. У п’ятому вертикальному стовпчику знаходиться два шари матеріалу, тому необхідно знайдену суму середніх ліній двох трапецій помножити на $\Delta l$ i $\Delta h$ і т.д. Самий високий стовпчик буде містити дев’ять шарів матеріалу. Відповідно знайденим об'ємам матеріалу у послідовно розташованих стовпчиках нижньої частини піскового тіла на рис.5 побудована залежність 1 , де висота колонок відповідає змісту пісків. 3 неї видно, що об'єм матеріалу у початковій частині піскового тіла достатньо малий, потім він плавно зростає, досягаючи максимуму у центральній частині, згодом плавно зменшується до такої ж як і в початковій фазі величини. Отриману залежність можливо апроксимувати виразом

$$
V=8940 \exp \left[-\left(l-l_{c p}\right)^{2} / 909\right], \mathrm{cm}^{3}
$$

де $l$ - довжина піскового тіла механічного спірального класифікатора вздовж осі, що змінюється від 10 до 120 см; $l_{c p}-$ середнє значення довжини, що дорівнює 60 см; 8940 - константа, що виражена в см³ 909 - константа, що виражена в $\mathrm{cm}^{3}$.

Графік, що відповідає залежності (8), побудовано на рис.5 (крива 2). 3 нього видно, що вираз (8) достатньо точно відтворює закономірність розташування матеріалу вздовж нижньої частини піскового тіла механічного спірального класифікатора. При отриманні даних залежностей коректно обгрунтовувались підходи і застосовувались випробувані методи досліджень, математичний апарат, що гарантує достовірність кінцевого результату. Тому отриману залежність можливо використовувати в процесах аналітичних досліджень режимів роботи механічних спіральних класифікаторів.

\section{Висновок}

Отже, розроблено підхід математичного моделювання і отримана конкретна закономірність розташування матеріалу вздовж нижньої частини піскового тіла механічного спірального класифікатора. Встановлено, що в 
механічному спіральному класифікаторі 1КСН-30 нижня частина піскового тіла в об’ ємному вираженні складає послідовний ряд вертикальних стовпчиків, об'єм матеріалу в яких підпорядкований експоненціальній залежності з максимумом кількості в центральній його частині, який визначається продуктивністю пісків. Дану залежність можливо використовувати при аналітичному дослідженні режимів роботи різних типів механічних спіральних класифікаторів.

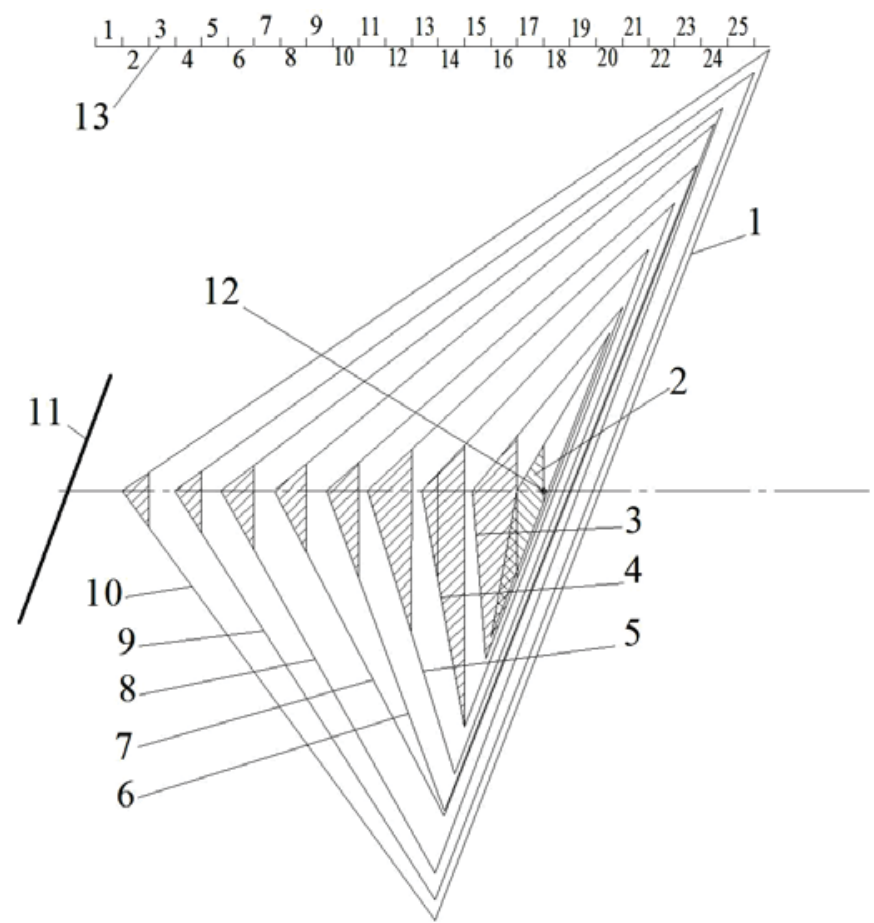

1 - проекції ліній змочування; 2...10 - відповідно проекції 1, 2, 3, 4, 5, 6, 7, 8, 9шарів матеріалу нижньої частини піскового тіла; 11 - проекція початкової частини переднього витка; 12 - центральна точка побудови проекцій; 13 номера стовпчиків з матеріалом

Рис.4 - Проекції нормалізованих геометричних фігур, що відповідають шарам нижньої частини піскового тіла, на горизонтальну площину, в якій знаходиться верхня поверхня найвищого шару

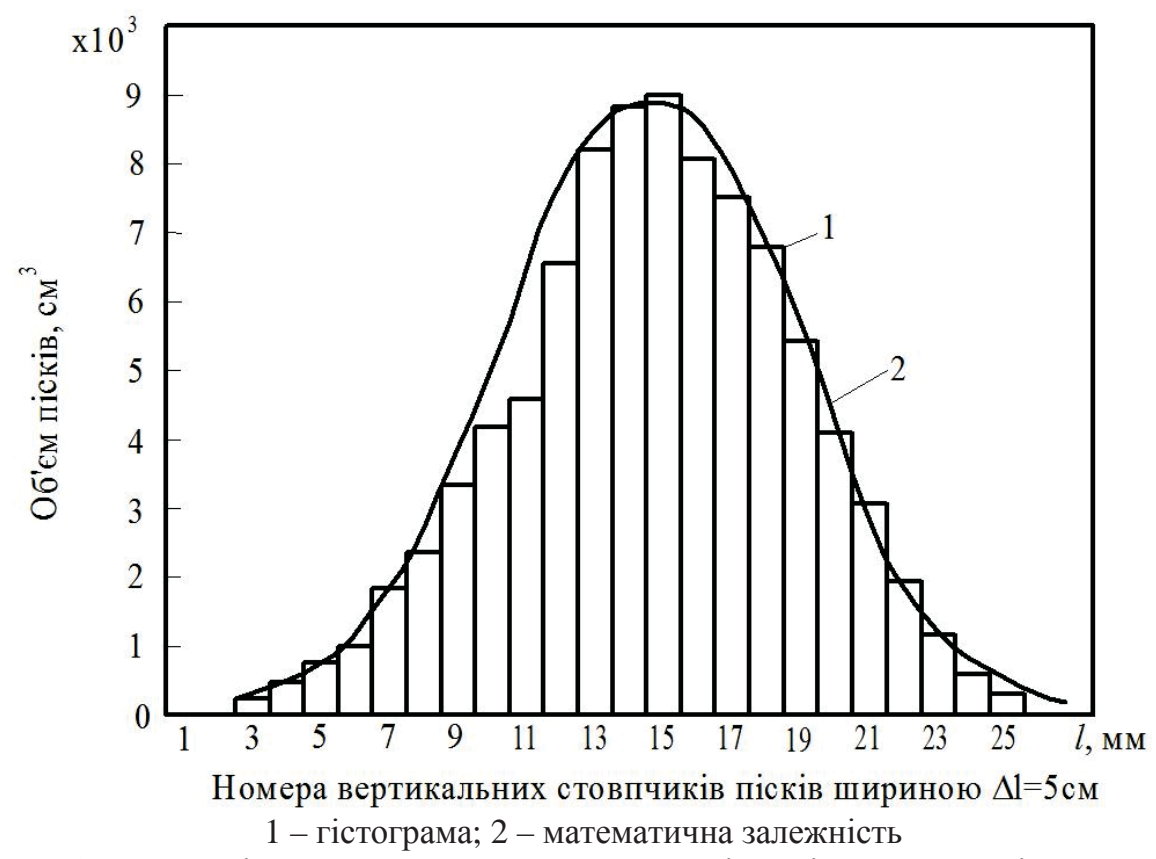

Рис.5 - Значення об’ єму матеріалу в вертикальних стовпчиках і аналітична залежність, що характеризують закономірність розташування матеріалу вздовж нижньої частини піскового тіла механічного спірального класифікатора 
На підставі проведених досліджень надається можливість встановлювати закономірності сходження пісків і руху пульпи у піскових жолобах механічних спіральних класифікаторів.

\section{Література}

[1] Моркун В.С. Формирование робастного автоматизированного управления замкнутым циклом измельчения на основе $\mathrm{H}_{\infty}$-нормы / В.С. Моркун, Н.В.Моркун, В.В.Тронь // Гірничий вісник: наук.-техн. зб. ДВНЗ «КНУ».- 2014.Вип. 98.- С. 83-85;

[2] Азарян А.А. Автоматизация первой стадии измельчения, классификации и магнитной сепарации - реальный путь повышения эффективности обогащения железных руд / А.А. Азарян, Ю.Ю. Кривенко, В.Г. Кучер // Вісник Криворізького національного університету: зб. наук. праць.- 2014.- Вип. 36.- С. 276-280;

[3] Ультразвуковой контроль характеристик измельченных материалов в АСУ ТП обогатительного производства / [Моркун В. С., Потапов В. Н., Моркун Н. В., Подгородецкий Н. С.]. - Кривой Рог : Изд. центр КТУ, 2007. - 283 c.;

[4] А.с. 1530258 СССР, МКИ В 03 В 13/00. Способ определения продуктивности спирального классификатора по пескам / Е.Ф. Морозов (СССР). - № 4385577/22-03; заявл. 29.02.88; опубл. 23.12.89, Бюл. № 47;

[5] Верхотуров М.В. Гравитационные методы обогащения / Верхотуров М.В.- М.: МАКС Пресс, 2006.- 352c.;

[6] Бронштейн И.Н. Справочник по математике для инженеров и учащихся вузов / И.Н. Бронштейн, К.А. Семендяев.- М.: Гос. изд. физико-математической лит., 1959.- 608 с.

[7] Мацуй А.М. Математичне моделювання формування піскового тіла у міжвитковому просторі механічного спірального класифікатора / А.М. Мацуй // Автоматизація технологічних і бізнес-процесів.- 2015.- №4.- С.9-17.

\section{References}

[1] Morkun V.S. Formirovanie robastnogo avtomatizirovannogo upravleniya zamknutym tsiklom izmel'cheniya na osnove Nœ-normy / V.S. Morkun, N.V.Morkun, V.V.Tron' // Girnichii visnik: nauk.-tekhn. zb. DVNZ «KNU».- 2014.- Vip. 98.S. 83-85;

[2] Azaryan A.A. Avtomatizatsiya pervoi stadii izmel'cheniya, klassifikatsii i magnitnoi separatsii - real'nyi put' povysheniya effektivnosti obogashcheniya zheleznykh rud / A.A. Azaryan, Yu.Yu. Krivenko, V.G. Kucher // Visnyk Kryvoriz'kogo nacional'nogo universytetu: zb. nauk. prac'.- 2014.- Vyp. 36.- S. 276-280;

[3] Ul'trazvukovoi kontrol' kharakteristik izmel'chennykh materialov v ASU TP obogatitel'nogo proizvodstva / [Morkun V. S., Potapov V. N., Morkun N. V., Podgorodetskii N. S.]. - Krivoi Rog : Izd. tsentr KTU, 2007. - 283 s.;

[4] A.s. 1530258 SSSR, MKI V 03 V 13/00. Sposob opredeleniya produktivnosti spiral'nogo klassifikatora po peskam / E.F. Morozov (SSSR). - № 4385577/22-03; zayavl. 29.02.88; opubl. 23.12.89, Byul. № 47;

[5] Verkhoturov M.V. Gravitatsionnye metody obogashcheniya / Verkhoturov M.V.- M.: MAKS Press, $2006 .-352$ s.;

[6] Bronshtein I.N. Spravochnik po matematike dlya inzhenerov i uchashchikhsya vuzov / I.N. Bronshtein, K.A. Semendyaev.- M.: Gos. izd. fiziko-matematicheskoi lit., 1959.- 608 s.

[7] Macuj A.M. Matematychne modeljuvannja formuvannja piskovogo tila u mizhvytkovomu prostori mehanichnogo spiral'nogo klasyfikatora / A.M. Macuj // Avtomatyzacija tehnologichnyh i biznes-procesiv.- 2015.- №4.- S.9-17.

\section{AUTOMATION NEWS}

\section{The first in the history operation in the face of the person is performed by means of the robot surgeon}

Surgeons from John Radcliff's (John Radcliffe Hospital) Hospital, Oxford, Great Britain, remotely made operation in the face of the person, having raised by means of the specialized robot a membrane which thickness is the 100-th part of millimeter and which covers an eye retina. This operation, according to information from Academy of World records (World Record Academy), is the first in the history of the automated operation in the field of eye surgery.

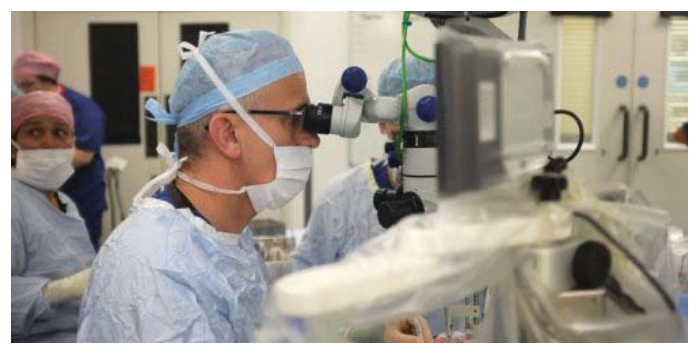

For carrying out operation surgeons used the Robotic robot Retinal Dissection Device (R2D2) which is intended for remote carrying out operations on a retina. But the most important feature of this device is that it is capable to smooth and suppress completely a tremor of arms of the surgeon, even those which are caused by pulse of its heartbeat. 